\title{
Author Correction: Farnesoid $X$ receptor activation inhibits TGFBR1/TAK1-mediated vascular inflammation and calcification via miR-135a-5p
}

\author{
Chao Li, Shijun Zhang, Xiaoqing Chen, Jingkang Ji, Wenqing Yang, Ting Gui, Zhibo Gai (D) \& Yunlun Li (D)
}

Correction to: Communications Biology https://doi.org/10.1038/s42003-020-1058-2, published online 24 June 2020.

In the original version of the published article, the image shown in Fig. 1h labelled as Pi + Ca (TGFBR1 siRNA) was incorrect. The image has been replaced with the correct photograph in the HTML and PDF versions of the article. The incorrect figure panel is reproduced here.

Published online: 06 November 2020

\begin{abstract}
(c) (i) Open Access This article is licensed under a Creative Commons Attribution 4.0 International License, which permits use, sharing, adaptation, distribution and reproduction in any medium or format, as long as you give appropriate credit to the original author(s) and the source, provide a link to the Creative Commons license, and indicate if changes were made. The images or other third party material in this article are included in the article's Creative Commons license, unless indicated otherwise in a credit line to the material. If material is not included in the article's Creative Commons license and your intended use is not permitted by statutory regulation or exceeds the permitted use, you will need to obtain permission directly from the copyright holder. To view a copy of this license, visit http://creativecommons.org/licenses/by/4.0/.
\end{abstract}

(C) The Author(s) 2020 


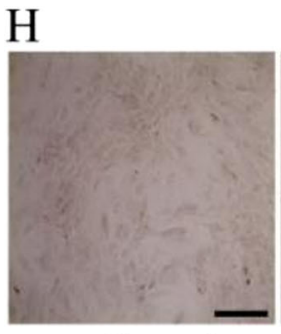

Control

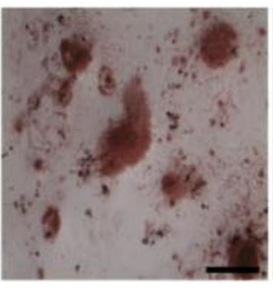

$\mathrm{Pi}+\mathrm{Ca}$
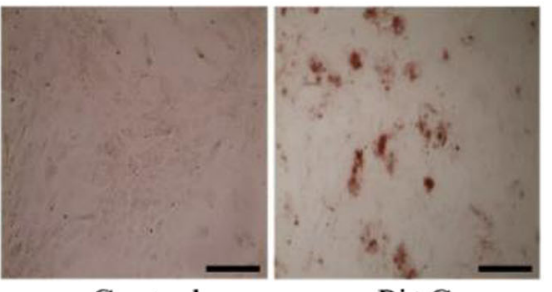

TGFBR1 siRNA

Fig. 1 